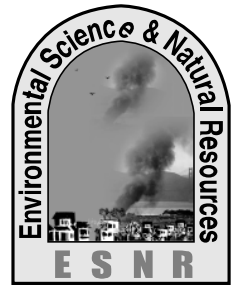

\title{
Effect of Growth Regulator on Regeneration of Sweet Potato (Ipomoea Batatas L.)
}

\author{
M. M. Kamal, M. H. Rahman ${ }^{1}$ and M. S. Haque \\ Dept. of Biotechnology, ${ }^{1}$ Dept. of Horticulture, Bangladesh Agricultural University, Mymensingh
}

\begin{abstract}
The experiment was conducted to investigate the effect of various concentrations of different growth regulators on the aspect of callus induction along with shoot regeneration and root formation of sweet potato viz. BARI 6. For callus induction, MS medium was used supplemented with different concentrations of 2,4-D and Kinetin. Different concentrations of BAP were used for shoot regeneration. Different concentrations of NAA and a constant level of BAP were also used for root development. For callus characters, 2,4-D at $0.5 \mathrm{mg} \mathrm{L}^{-1}+$ kinetin at $0.5 \mathrm{mg} \mathrm{L}^{-1}$ Treatments we the maximum callus induction (90.00\%), highest weight of callus at 15 days $(4.64 \mathrm{~g})$ and 35 days $(5.63 \mathrm{~g})$ of culture while similar treatment requiring the minimum time (5.67 days) to callus initiation. Among the various concentrations of BAP, maximum shoot regeneration (81.67\%), minimum time (7.33 days) for shoot initiation, maximum leaves $\operatorname{shoot}^{-1}(11.92)$ and longest shoot $(5.25 \mathrm{~cm})$ were recorded in $2.50 \mathrm{mg} \mathrm{L}^{-1} \mathrm{BAP}$ while BAP at $2.0 \mathrm{mg} \mathrm{L}^{-1}$ in combination with NAA at $1.0 \mathrm{mg} \mathrm{L}^{-1}$ observed the maximum root formation $(71.67 \%)$ and longest root $(10.58 \mathrm{~cm})$ with an average minimum time for root initiation (7.50 days) in the present study.
\end{abstract}

Key words: Growth regulators, Regeneration, Sweet potato

\section{Introduction}

The sweet potato (Ipomoea batatas L. Lam.) is a dicotyledonous plant that belongs to the family Convolvulaceae, order Polemoniales and found by Columbus and his shipmates. Sweet potato is also an important crop in Bangladesh. It is the fourth largest crop in Bangladesh after rice, wheat and potato (BBS, 2008). The country produced 307 thousand metric tons of sweet potatoes in an area of 78 thousands acres of land and the average yield was 3.94 metric tons acre ${ }^{-1}$ during the year 2007-08 which was lower than before year (BBS, 2008). It is evident from the above statistics that the production of the crop is gradually decreasing in this country. Besides, simple starches, sweet potatoes are rich in complex, carbohydrates, dietary fiber, beta carotene, vitamin C and vitamin $B_{6}$. Sweet potato provides nutritionally significant quantities of riboflavin, iron, calcium, copper, potassium and protein. The sweet potato is conventionally propagated by vine cuttings in the field and thus susceptible to cumulative infection by fungi, bacteria, viruses and viroids. These infections cause degeneration of the crop resulting yield reduction. Tissue culture is an important field of biotechnology and has a potential to improve the quality and quantity of vegetatively propagated sweet potato. Establishment of an efficient plant regeneration system for the sweet potato grown in Bangladesh will be highly useful. Sweet potato plant can be regenerated in vitro from explants of many parts (Hossain et al., 1999; Cheng and Yeh, 2003). The techniques have not only the potential of producing a large number of propagules within a single year but also have added advantage of built in disease protection. Rapid multiplication by tissue culture would enable newly selected varieties to be bulked up in a disease free condition for commercial use. It is well documented that in vitro techniques are used to be an effective tool for improvement of sweet potato. So, far, in vitro techniques for regeneration of sweet potato are not established in Bangladesh. Therefore, there is a need for successful regeneration technique for improvement of sweet potato. The present experiment was undertaken to study the effect of various concentration of growth regulator on the aspect of callus induction, shoot regeneration and root formation of sweet potato.

\section{Materials and Methods}

The research program reported here was carried out during the period from May to September 2010 in the USDA Biotechnology Laboratory, Department of Biotechnology, Bangladesh Agricultural University (BAU), Mymensingh. The variety BARI 6 of sweet potato was used as experimental materials which was collected from the Bangladesh Agricultural Research Institute, Gazipur-1701. Leaf of sweet potato was used for callus induction on MS medium supplemented with different concentrations of 2,4-D (0.0. $0.1,0.5$ and $1.0 \mathrm{mg} \mathrm{L}^{-1}$ ) in combinations with different concentrations of Kinetin $(0.0,0.1,0.5$ and $\left.1.0 \mathrm{mg} \mathrm{L}^{-1}\right)$. After callus induction, calli were used for shoot regeneration in different concentrations of BAP (0.0. 1.5, 2.5, 3.5 and $4.5 \mathrm{mg} \mathrm{L}^{-1}$ ). The regenerated shoot was rooted on MS medium supplemented with different concentrations of NAA (0.0. $0.1,0.5$ and $1.0 \mathrm{mg} \mathrm{L}^{-1}$ ) in combination with a constant level of BAP $\left(2.0 \mathrm{mg} \mathrm{L}^{-1}\right)$. To investigate the effect of different treatments of growth regulators on callus induction, shoot regeneration and root formation, the data were recorded on days to callus 
induction, callus induction (\%), weight of callus at 15 and 35 days of culture, shoot regeneration (\%), days to shoot initiation, number of leaves shoot ${ }^{-1}$, shoot length, percent shoot sowing root, days to root and length of root. The collected data were analyzed statistically and means were adjudged by DMRT at $5 \%$ level of probability (Gomez and Gomez, 1984).

\section{Results and Discussion}

The effect of different concentrations of two hormones combination such as 2,4-D and kinetin was significantly influenced on various callus characters viz. per cent callus induction, days to callus and weight of callus at both 15 and 45 days of culture (Table 1). From the table 1, it is evident that the treatment combination of $0.5 \mathrm{mg} \mathrm{L}^{-1} 2,4-\mathrm{D}+0.5 \mathrm{mg}$ $\mathrm{L}^{-1}$ kinetin was more effective to produce greater results on callusing compare to other treatment combinations of 2,4-D and kinetin. As a result, 0.5 $\mathrm{mg} \mathrm{L}^{-1} 2,4-\mathrm{D}+0.5 \mathrm{mg} \mathrm{L}^{-1}$ kinetin produced the maximum callus induction $(90.00 \%)$, highest weight of callus at 15 days $(4.64 \mathrm{~g})$ and 35 days $(5.63 \mathrm{~g})$ of culture while similar treatment requiring the minimum time (5.67 days) to callus initiation whereas it was closely followed by the treatment combinations of $0.5 \mathrm{mg} \mathrm{L}^{-1} 2,4-\mathrm{D}+0.1 \mathrm{mg} \mathrm{L}^{-1}$ kinetin in respect of callus weight at both 15 and 35 (4.42 and $5.63 \mathrm{~g}$, respectively) days of callus culture. Among other treatment combinations of hormones, it was found that the minimum callus induction $(20.00 \%)$, lowest weight of callus at $15(0.78 \mathrm{~g})$ and $35(1.79 \mathrm{~g})$ days of culture were observed in $0.0 \mathrm{mg} \mathrm{L}^{-1} 2,4-\mathrm{D}+0.1 \mathrm{mg}$ $\mathrm{L}^{-1}$ kinetin while without any hormone concentration (control) unable to produce any callus during study (Table 1). These results indicated that the combination of both hormones such as 2,4-D and kinetin would be effective for callus culture of sweet potato. The present results was also similar to the findings of Wang et al. (1999) where they reported that MS medium supplemented with 0.02 or $0.05 \mathrm{mg}$ $\mathrm{L}^{-1} 2,4-\mathrm{D}$ and $0.5 \mathrm{mg} \mathrm{L}^{-1}$ kinetin would be used for callus induction.

Table 1. Effects of sweet potato varieties on regeneration of callus, days to callus and weight of callus at 15 and 35 days after callus initiation

\begin{tabular}{|c|c|c|c|c|}
\hline \multirow{2}{*}{$\begin{array}{c}\mathbf{2}-\mathbf{D}+\mathbf{K n} \\
\left(\mathbf{m g ~ L}^{-\mathbf{1}}\right)\end{array}$} & \multirow{2}{*}{ Callus induction (\%) } & \multirow{2}{*}{ Days to callus initiation } & \multicolumn{2}{|c|}{ Weight of callus (g) at } \\
\cline { 4 - 5 } & & $\mathbf{1 5}$ days & $\mathbf{3 5}$ days \\
\hline $0+0$ & $0.00 \mathrm{j}$ & 0.00 & $0.00 \mathrm{j}$ & $0.00 \mathrm{k}$ \\
\hline $0+0.1$ & $20.00 \mathrm{i}$ & 11.50 & $0.78 \mathrm{i}$ & $1.79 \mathrm{j}$ \\
\hline $0+0.5$ & $26.67 \mathrm{~h}$ & 10.92 & $0.93 \mathrm{hi}$ & $1.95 \mathrm{i}$ \\
\hline $0+1.0$ & $33.33 \mathrm{~g}$ & 9.50 & $0.97 \mathrm{~h}$ & $1.99 \mathrm{i}$ \\
\hline $0.1+0$ & $24.17 \mathrm{~h}$ & 10.08 & $1.04 \mathrm{~h}$ & $2.02 \mathrm{i}$ \\
\hline $0.1+0.1$ & $38.33 \mathrm{f}$ & 9.75 & $1.69 \mathrm{~g}$ & $2.72 \mathrm{~h}$ \\
\hline $0.1+0.5$ & $55.00 \mathrm{de}$ & 8.50 & $2.25 \mathrm{f}$ & $3.28 \mathrm{~g}$ \\
\hline $0.1+1.0$ & $67.50 \mathrm{c}$ & 7.92 & $3.43 \mathrm{~d}$ & $4.28 \mathrm{de}$ \\
\hline $0.5+0$ & $31.67 \mathrm{~g}$ & 9.50 & $3.03 \mathrm{e}$ & $4.10 \mathrm{e}$ \\
\hline $0.5+0.1$ & $53.08 \mathrm{e}$ & 7.75 & $4.42 \mathrm{ab}$ & $5.63 \mathrm{ab}$ \\
\hline $0.5+0.5$ & $90.00 \mathrm{a}$ & 5.67 & $4.64 \mathrm{a}$ & $5.89 \mathrm{a}$ \\
\hline $0.5+1.0$ & $83.33 \mathrm{~b}$ & 7.17 & $4.23 \mathrm{~b}$ & $5.29 \mathrm{~b}$ \\
\hline $1.0+0$ & $57.50 \mathrm{~d}$ & 7.50 & $3.77 \mathrm{c}$ & $4.88 \mathrm{c}$ \\
\hline $1.0+0.1$ & $52.50 \mathrm{e}$ & 9.08 & $3.34 \mathrm{~d}$ & $4.44 \mathrm{~d}$ \\
\hline $1.0+0.5$ & $68.33 \mathrm{c}$ & 8.00 & $3.34 \mathrm{~d}$ & $5.02 \mathrm{~b}$ \\
\hline $1.0+1.0$ & $55.00 \mathrm{de}$ & 9.83 & 2.08 & $3.52 \mathrm{f}$ \\
\hline Sig. level & $*$ & $* *$ & $* *$ & $* * 2$ \\
\hline CV $(\%)$ & $\mathbf{1 9 . 3 4}$ & $\mathbf{1 3 . 3 4}$ & $\mathbf{2 . 2 1}$ & $\mathbf{2 . 7 3}$ \\
\hline
\end{tabular}

Effect of various concentrations of BAP significantly influenced on days to shoot, number of leaves and length of shoot while regeneration of shoot was not significant (Table 2). However, regeneration of shoot did not differ significantly but regeneration of shoot from calli had maximum $(81.67 \%)$ in $2.50 \mathrm{mg} \mathrm{L}^{-1}$ BAP and minimum $(45.00 \%)$ in $4.5 \mathrm{mg} \mathrm{L}^{-1}$ BAP. Similarly, $2.5 \mathrm{mg} \mathrm{L}^{-1}$ BAP requiring the minimum time (7.33 days) for shoot initiation which also produced maximum number of leaves shoot ${ }^{-1}$ (11.92) and longest shoot $(5.25 \mathrm{~cm})$ compare to other concentrations of BAP. Among other concentrations of BAP, BAP at $4.5 \mathrm{mg} \mathrm{L}^{-1}$ required maximum time (13.50 days) for shoot initiation, minimum number of leaves $\operatorname{shoot}^{-1}$ (3.58) and shortest shoot $(2.42 \mathrm{~cm})$ while without BAP, it did not produce any shoot (Table 2). These result revealed that BAP at $2.50 \mathrm{mg}$ $\mathrm{L}^{-1}$ would be appropriate concentration for shoot 
regeneration of sweet potato. Similarly, Wang et al. (1999) reported that shoot regeneration was promoted by BAP in petiole callus of sweet potato viz. Genki.

Table 2. Effects of different concentrations of BAP on regeneration of shoot, days to shoot, number of leaves shoot $^{-1}$ and length of shoot

\begin{tabular}{|l|c|c|c|c|}
\hline $\begin{array}{c}\text { BAP } \\
\left(\mathbf{m g ~ L}^{-\mathbf{1}}\right)\end{array}$ & $\begin{array}{c}\text { Regeneration of shoot } \\
(\boldsymbol{\%})\end{array}$ & $\begin{array}{c}\text { Days to shoot } \\
\text { initiation }\end{array}$ & $\begin{array}{c}\text { Number of leaves } \\
\text { shoot }^{\mathbf{~}}\end{array}$ & Length of shoot (cm) \\
\hline 0 & 0.0 & 0.0 & $0.0 \mathrm{e}$ & $0.0 \mathrm{~d}$ \\
\hline 1.5 & 66.67 & 9.50 & $8.75 \mathrm{~b}$ & $4.50 \mathrm{~b}$ \\
\hline 2.5 & 81.67 & 7.33 & $11.92 \mathrm{a}$ & $5.25 \mathrm{a}$ \\
\hline 3.5 & 54.17 & 12.08 & $6.75 \mathrm{c}$ & $4.58 \mathrm{~b}$ \\
\hline 4.5 & 45.00 & 13.50 & $3.58 \mathrm{~d}$ & $2.42 \mathrm{c}$ \\
\hline Sig. level & $\mathbf{n S}$ & $* *$ & $* *$ & $* *$ \\
\hline CV $(\%)$ & $\mathbf{1 6 . 0 8}$ & $\mathbf{1 3 . 7 8}$ & $\mathbf{1 5 . 3 0}$ & $\mathbf{1 9 . 2 7}$ \\
\hline
\end{tabular}

A significant variation was also found by the effect of various concentrations of NAA on root formation, days to root initiation and length of root while BAP at $2.0 \mathrm{mg} \mathrm{\textrm {L } ^ { - 1 }}$ was used as supplemented with NAA levels (Table 3). Among the various concentrations of $\mathrm{NAA}$, it was found that the NAA at $1.0 \mathrm{mg} \mathrm{L}^{-1}$ produced the maximum shoot showing root $(71.67 \%)$ and longest root $(10.58 \mathrm{~cm})$ which was followed by $0.5 \mathrm{mg} \mathrm{L}^{-1} \mathrm{NAA}(65.00 \%$ and $9.83 \mathrm{~cm}$, respectively). $\mathrm{NAA}$ at $1.0 \mathrm{mg} \mathrm{L}^{-1}$ also requiring the minimum time for root initiation (7.50 days) while application of 0.5 $\mathrm{mg} \mathrm{L}^{-1}$ NAA requiring the statistically similar time (7.92 days) for root initiation (Table 3). However, root formation from shoot had minimum (29.67\%) with an average maximum requiring time (11.50 days) for root initiation in $0.1 \mathrm{mg} \mathrm{L}^{-1} \mathrm{NAA}$ but 1.5 $\mathrm{mg} \mathrm{L}^{-1}$ NAA produced the shortest root $(5.58 \mathrm{~cm})$. These results indicated that $1.0 \mathrm{mg} \mathrm{L}^{-1}$ NAA would be optimum concentration and more effective to produce more and earlier root formation, longest root was also found under this treatment in this study. The result of the present study was agreed to the finding of Gao et al. (1999) who found that the optimum medium contained $1.0 \mathrm{mg} \mathrm{NAA} \mathrm{L}^{-1}$ for root differentiation and $0.1 \mathrm{mg} \mathrm{L}^{-1}$ for root growth of sweet potato. Besides, they also found that the concentration of NAA seemed to be the most important factor for root differentiation and growth.

Table 3. Effects of different concentrations of NAA with BAP at $2.0 \mathrm{mg} \mathrm{L}^{-1}$ on formation of root, days to root and length of root

\begin{tabular}{|l|c|c|c|}
\hline $\begin{array}{c}\text { NAA } \mathbf{~} \mathbf{1} \text { ) } \\
\text { (mg } \mathbf{~}^{-}\end{array}$ & Root formation $(\%)$ & Days to root initiation & Length of root (cm) \\
\hline 0 & $0.0 \mathrm{e}$ & $0.0 \mathrm{~d}$ & $0.0 \mathrm{e}$ \\
\hline 0.1 & $29.67 \mathrm{~d}$ & $11.50 \mathrm{a}$ & $7.33 \mathrm{c}$ \\
\hline 0.5 & $65.00 \mathrm{~b}$ & $7.92 \mathrm{c}$ & $9.83 \mathrm{~b}$ \\
\hline 1.0 & $71.67 \mathrm{a}$ & $7.50 \mathrm{c}$ & $10.58 \mathrm{a}$ \\
\hline 1.5 & $45.33 \mathrm{c}$ & $10.33 \mathrm{~b}$ & $5.58 \mathrm{~d}$ \\
\hline Sig. level & $* *$ & $* *$ & $* *$ \\
\hline CV $(\%)$ & $\mathbf{1 8 . 0 4}$ & $\mathbf{1 2 . 2 5}$ & $\mathbf{1 4 . 1 0}$ \\
\hline
\end{tabular}

From the above result it was found that the $0.5 \mathrm{mg} \mathrm{L}^{-1}$ 2,4-D + $0.5 \mathrm{mg} \mathrm{L}^{-1}$ kinetin for callus induction, 2.5 $\mathrm{mg} \mathrm{L}^{-1}$ BAP for shoot regeneration and $1.0 \mathrm{mg} \mathrm{L}^{-1}$ NAA supplemented with $2.0 \mathrm{mg} \mathrm{L}^{-1}$ BAP for root formation were optimum concentration in the present study.

\section{References}

BBS, 2008. Statistical Year Book of Agriculture. Bangladesh Bureau of Statistics. Govt. of the Peoples Republic of Bangladesh.
Cheng, H. and Yeh, M. 2003. Studies on tissue culture of sweet potato. The effects of different kinds and concentration of auxin on plant regeneration of explants from different parts. J. Agril. Forestry, 52(3): 63-79.

Gao, F.; Gong, Y. F. and Wang, X. 1999. High frequency induction of adventitious root differentiation and culture factor optimization in tissue culture of Ipomoea batatas (L.) Lam. J. Southwest Agril. Univ., 21(5): 417-422. 
Gomez, K. A. and Gomez, A. A. 1984. Statistical Procedure for Agricultural Research. Int. Rice Res. Inst. John Wiley and Sons, New York. pp. 139-240.

Hossain, M. J.; Sultana, N. and Ahmad, A. U. 1999. In vitro performance of five standard sweet potato cultivars (Ipomoea batatas). Plant Tiss. Cult., 9: 151-157.

Wang, J.; Sato, M. and Taura, S. 1999. High frequency plant regeneration in leaf and petiole explant cultures of sweet potato. Memoirs of the Faculty of Agric, Kagoshima Univ., 35: 1-5. 